\title{
Comparative Proteomic Analysis of Two Barley Cultivars (Hordeum vulgare L.) with Contrasting Grain Protein Content
}

Baojian Guo ${ }^{1 \dagger}$, Haiye Luan ${ }^{1,2+}$, Shen Lin ${ }^{1}$, Chao Lv', Xinzhong Zhang ${ }^{1}$ and Rugen $X u^{1 *}$

' Jiangsu Key Laboratory of Crop Genetics and Physiology/Co-Innovation Center for Modern Production Technology of Grain Crops, Key Laboratory of Plant Functional Genomics of the Ministry of Education, Barley Research Institution of Yangzhou University, Yangzhou University, Yangzhou, China, ${ }^{2}$ JiangSu Coastal Area Institute of Agricultural Sciences, Yancheng, China

Grain protein contents (GPCs) of barley seeds are significantly different between feed and malting barley cultivars. However, there is still no insight into the proteomic analysis of seed proteins between feed and malting barley cultivars. Also, the genetic control of barley GPC is still unclear. GPCs were measured between mature grains of Yangsimai 3 and Naso Nijo. A proteome profiling of differentially expressed protein was established by using a combination of 2-DE and tandem mass spectrometry. In total, 502 reproducible protein spots in barley seed proteome were detected with a pH range of 4-7 and 6-11, among these 41 protein spots (8.17\%) were detected differentially expressed between Yangsimai 3 and Naso Nijo. Thirty-four protein spots corresponding to 23 different proteins were identified, which were grouped into eight categories, including stress, protein degradation and post-translational modification, development, cell, signaling, glycolysis, starch metabolism, and other functions. Among the identified proteins, enolase (spot 274) and small subunit of ADP-glucose pyrophosphorylase (spot 271) are exclusively expressed in barley Yangsimai 3, which may be involved in regulating seed protein expression. In addition, malting quality is characterized by an accumulation of serpin protein, Alpha-amylase/trypsin inhibitor CMb and Alpha-amylase inhibitor BDAl1. Most noticeably, globulin, an important storage protein in barley seed, undergoes post-translational processing in both cultivars, and also displays different expression patterns.

Keywords: barley, grain protein content, two-dimensional electrophoresis, differentially expressed protein, mass spectrometry

\section{INTRODUCTION}

Barley is the fourth largest cereal crop in the world, which is not only widely used for food and feed, but also used for malting and brewing. The former requires grain protein content (GPC) to be as high as possible, whereas malting barley requires GPC to be at the proper level (See et al., 2002; Clancy et al., 2003; Cai et al., 2013). In Europe, the acceptable protein content range for malting barley was 9.5-11.5\% (Pettersson and Eckersten, 2007). Higher protein content levels resulted in excess extract yield, which could produce a beer with hazy appearance; while lower protein levels decreased enzyme activity (Weston et al., 1993; Eagles et al., 1995). In addition, a 
positive correlation has been observed between GPC and diastatic power (Wang et al., 2003; Cai et al., 2013).

Barley GPC revealed significant differences in different varieties. Cai et al. (2013) analyzed the GPC of 59 cultivated and 99 Tibetan wild barley accessions in 2008 and 2009. The results showed that the GPC ranged from 8.02 to $13.50 \%$ with a mean of $10.56 \%$ in 2008 and ranged from 8.28 to $14.45 \%$ with a mean of $10.87 \%$ in 2009 . Tibetan wild barley was found to have a higher GPC than cultivated barley. Comparative GPC analysis performed in 10 two-rowed spring malting barley cultivars showed that Klages and Logan showed the highest (14.57\%) and lowest (12.56\%) GPC, respectively, (Qi et al., 2005). Remarkably, variation in the proportions of the individual B, C, and D hordeins was observed in barley cultivars (Howard et al., 1996; Qi et al., 2005). All the above results indicated that genetic background had significant effects on GPC.

Recently, Two-dimensional electrophoresis combined with tandem mass spectrometry (MS) have resulted in new insights into the molecular basis of grain filling and seed maturation in plants (Finnie et al., 2002; Ge et al., 2012; Guillon et al., 2012; Dong et al., 2014; Jiang et al., 2014). For example, two-dimensional gel electrophoresis was used for a timeresolved study of the changes in proteins that occur during seed development in barley with approximately 1,000 lowsalt extractable protein spots detected on the two dimensional gels. Among which 19 protein spots were identified by using matrix-assisted laser-desorption ionization time of flight MS or nano-electrospray tandem MS/MS. Proteins were accumulated throughout grain filling and maturation stages, which is reported to be functional characteristics of barley cultivars (Finnie et al., 2002). Glutelin is a predominant compound in rice seed. Two-dimensional gel electrophoresis (2-DE) analysis revealed remarkable differences in protein profiles of the wild rice species and the two cultivated rice materials. A total of 35 different pattern of expression protein spots were found for glutelin acidic subunits, glutelin precursors and glutelin basic subunits in wild rice species. Among those, 18 protein spots were specific and 17 major spots were elevated (Jiang et al., 2014). Chinese bread wheat cultivars Jimai 20 and Zhoumai 16 with different quality properties were investigated by $2-\mathrm{DE}$ and MALDI-TOF/TOF-MS. A total of 117 different pattern of expression protein spots representing 82 unique proteins, which included isocitrate dehydrogenase, triticin precursor, lowmolecular-weight glutenin subunit, and replication factor C-like protein. Remarkably, Class II chitinase and peroxidase 1 with isoforms in developing grains were shown to be phosphorylated by Pro-Q Diamond staining and phosphorylated protein site prediction (Guo et al., 2012). Therefore, proteome analysis is a tool that can be used both to visualize and compare complex mixtures of proteins.

In the present study, we reported a comparative proteomics analysis between Yangsimai 3 (feed barley cultivar) and Naso Nijo (malting barley cultivar) by 2 -DE and tandem MS. The main objectives were: (1) to obtain comparative information on proteins expression profiling between feed barley and malting barley; and (2) to identify potential candidate proteins that influence GPC and barley grain quality.

\section{MATERIALS AND METHODS}

\section{Plant Material and Growth Conditions}

Barley cultivars Yangsimai 3 and Naso Nijo were used in this study. Yangsimai 3 is a Chinese landrace of feed barley, tworowed, with a high GPC. Naso Nijo is a Japanese two-rowed malting barley cultivar with a low GPC. Two barley cultivars were planted at the Yangzhou University Experimental Farm in the autumn of 2013. Twelve seeds of each cultivar were planted $10 \mathrm{~cm}$ apart with $20 \mathrm{~cm}$ between rows. The mature seeds were harvested from the middle region of the main spikelet, and then the seeds were frozen in liquid nitrogen and stored in $-80^{\circ} \mathrm{C}$ for protein extraction. Three biological replicates were undertaken with 100 seeds per genotype being used for protein extraction and GPC measurement for each replication.

\section{Grain Protein Content Measurement}

The mature grains were dried to a constant weight at $80^{\circ} \mathrm{C}$, and ground in a Cyclotec 1093 sample mill (Hoganas City, Sweden) and sieved through a $0.5 \mathrm{~mm}$ screen. The total nitrogen content in grain was quantified according to the Kjeldahl method by using FOSS Kjeltec TM 2300 (Foss Analytical AB, Sweden; Kjeldahl, 1883). GPC was calculated by using the following formula: $\mathrm{GPC}=$ Nitrogen content $\times 5.83 \times 100 \%$ (Sun et al., 2013). Statistical analysis of the differences in aerial part traits between cultivars was performed by using Student's $t$-test.

\section{Protein Extraction}

A 100 seeds of each genotype were pooled and milled to powder in liquid nitrogen. Approximately $0.1 \mathrm{~g}$ of flour was added into $1 \mathrm{~mL}$ of extraction buffer ( $2 \%$ SDS, $10 \%$ glycerol, $50 \mathrm{mM}$ DTT, $40 \mathrm{mM}$ Tris- $\mathrm{HCl}, \mathrm{pH} 6.8$ ) at $4^{\circ} \mathrm{C}$ (Hurkman and Tanaka, 2007). From this step onward, all manipulations were carried out at or below $4^{\circ} \mathrm{C}$. The detailed method was as follows: the flour was extracted with stirring for $30 \mathrm{~min}$ and the insoluble material was removed by centrifugation at 20,000 $\mathrm{g}$ for $30 \mathrm{~min}$ (Fullerton City, CA, USA). The supernatant containing protein fractions were precipitated with four volumes of cold acetone containing $0.07 \%$ DTT. After $2 \mathrm{~h}$ incubation at $-20^{\circ} \mathrm{C}$, the extracts were centrifuged at $18,000 \mathrm{~g}$ for $30 \mathrm{~min}$ at $4^{\circ} \mathrm{C}$ and the supernatant was discarded. Protein pellets were resuspended with cold $80 \%$ acetone containing $0.07 \%$ DTT, incubated for $1 \mathrm{~h}$ at $-20^{\circ} \mathrm{C}$ before centrifuging at $18000 \mathrm{~g}$ for $15 \mathrm{~min}$ at $4^{\circ} \mathrm{C}$ (Kim et al., 2013). This step was repeated five times and the protein pellet was freeze-dried under vacuum. Protein pellets were solubilized and incubated in a protein buffer [7 $\mathrm{M}$ urea, $2 \mathrm{M}$ thiourea, 2\% CHAPS (powder to solution, w/v), $0.5 \%$ IPG buffer (v/v; pH 4-7 and 6-11; Fairfield City, $\mathrm{OH}$, USA) and $36 \mathrm{mM} \mathrm{DTT}(5.6 \mathrm{mg} / \mathrm{mL})]$ at room temperature for $1 \mathrm{~h}$, vortexed every $10 \mathrm{~min}$. The mixture was then centrifuged $(20,000 \mathrm{~g})$ for $15 \mathrm{~min}$, and the supernatant was collected. Protein concentration was determined by Bradford assay (Bradford, 1976) with bovine serum albumin (BSA) used as a standard, and the $R^{2}$ of standard curve was 0.9974 (Supplementary Figure S1). 


\section{Two-dimensional Gel Electrophoresis and Image Analysis}

Seed protein extract $(200 \mu \mathrm{g})$ was loaded onto a GE Healthcare $18 \mathrm{~cm}$ IPG strip with a linear gradient of $\mathrm{pH} 4-7$ and $\mathrm{pH} 6-$ 11 during strip rehydration overnight. IEF was conducted using IPGPhorII (Fairfield City, OH, USA) at $20^{\circ} \mathrm{C}$ for a total of $65 \mathrm{kVh}$. Equilibration of the strips was performed immediately with $10 \mathrm{~mL}$ of two types of SDS equilibration buffer for $15 \mathrm{~min}$ each. Buffer 1 contained 1.5 M Tris- $\mathrm{HCl}$ (pH 8.8), $6 \mathrm{M}$ urea, 30\% glycerol, 2\% SDS, and 1\% DTT, and buffer 2 contained $1.5 \mathrm{M}$ Tris- $\mathrm{HCl}$ (pH 8.8), $6 \mathrm{M}$ urea, 30\% glycerol, $2 \%$ SDS, and 2.5\% iodoacetamide. The second dimension SDS-PAGE gels (12.5\% linear gradient) were run on an Ettan DALTsix (Fairfield City, $\mathrm{OH}, \mathrm{USA}), 0.5 \mathrm{~h}$ at $2.5 \mathrm{~W}$ per gel, then at $12 \mathrm{~W}$ per gel until the dye front reached the gel bottom. Upon electrophoresis, the protein spots were stained with silver nitrate according to the instructions of the PlusOne ${ }^{\mathrm{TM}}$ Silver Staining Kit for proteins (Fairfield City, OH, USA), which offered improved compatibility with subsequent mass spectrometric analysis. Briefly, gels were fixed in $40 \%$ ethanol and $10 \%$ acetic acid for $30 \mathrm{~min}$, and then sensitized with $30 \%$ ethanol, $0.2 \%$ sodium thiosulfate $(\mathrm{w} / \mathrm{v})$, and $6.8 \%$ sodium acetate $(\mathrm{w} / \mathrm{v})$ for $30 \mathrm{~min}$. Then gels were rinsed with distilled water three times; 5 min duration each time; then incubated in silver nitrate $(2.5 \mathrm{~g} / \mathrm{L})$ for $20 \mathrm{~min}$. Incubated gels were rinsed with distilled water and developed in a sodium carbonate solution $(25 \mathrm{~g} / \mathrm{L})$ with formaldehyde $(37 \%$, w/v) added $(300 \mu \mathrm{L} / \mathrm{L})$ before use. Development was stopped with $1.46 \%$ EDTA- $\mathrm{Na}_{2} \bullet 2 \mathrm{H}_{2} \mathrm{O}(\mathrm{w} / \mathrm{v})$, and gels were stored in distilled water until they could be processed and reproducible spots were removed from them. Gel images were acquired using Labscan (Fairfield City, OH, USA). Image analysis was carried out with Imagemaster 2D Platinum Software Version 7.0 (Fairfield City, OH, USA). Three biological replicates of silver stained gels showed high reproducibility ( $>95 \%$ ) by comparison using the Imagemaster 2D Platinum Software 7.0. Spot detection was performed automatically by the software used with the parameters smooth, minimum area, and saliency set to 2,15 , and 8 , respectively, followed by manual spot editing, such as spot deletion, spot splitting, and merging. All the gels were matched to the reference gel in automated mode with Imagemaster $2 \mathrm{D}$ Platinum Software 7.0. The volume of each spot from three replicate gels was normalized and quantified against total spot volume in the Imagemaster 2D Platinum Software 7.0. Sequential $\mathrm{k}$-nearest neighbor methods was used to impute missing values. Changes in the normalized spot volumes between experimental and control images were evaluated with a mixed linear mode. The spot number and normalized spot volume data were formatted in Excel. Student $t$-test analysis of protein expression was performed between Yangsimai 3 and Naso Nijo, and only those protein spots with the fold changes more than 1.5 and significant at $p<0.05$ were considered as differentially expressed proteins.

When comparing the different pattern of expression protein spots between Yangsimai 3 and Naso Nijo, both quantitative and qualitative differences were observed. The quantitative differences can be grouped into two categories: up-regulated or down-regulated protein spot in Yangsimai 3 compared with
Naso Nijo. The qualitative differences can be grouped into two categories: (i) specific expressed in Yangsimai 3 (SEY), expression in Yangsimai 3 cultivar, but not in Naso Nijo cultivar; (ii) specific expressed in Naso Nijo (SEN), expression in Naso Nijo cultivar, but not in Yangsimai 3 cultivar. Student's $t$-test $(p<0.05)$ was used to calculate significant differences in relative abundances of protein spot features in the Yangsimai 3 compared with Naso Nijo. Spots with reproducible and significant variations, at least 1.5-fold up-regulated or down-regulated, were considered quantitative differentially expressed proteins.

\section{In-gel Digestion of Proteins}

Protein spots were excised manually and transferred to $1.5 \mathrm{~mL}$ microcentrifuge tubes, and proteins with lower abundance were removed from all the replicate gels to pool and digest in a single tube. Protein spots were destained twice with $30 \mathrm{mM}$ potassium ferricyanide and $100 \mathrm{mM}$ sodium thiosulfate, and then rinsed with $25 \mathrm{mM}$ ammonium bicarbonate in $50 \%$ acetonitrile. Protein spots were dehydrated with $100 \%$ acetonitrile, dried under vacuum, and $10 \mu \mathrm{L}$ trypsin $(10 \mathrm{ng} / \mu \mathrm{L})$ was added, imbibed $40 \mathrm{~min}$ on ice. Then protein spots were covered by using $25 \mu \mathrm{L} 25 \mathrm{mM}$ ammonium bicarbonate and incubated for $16 \mathrm{~h}$ at $37^{\circ} \mathrm{C}$. The peptides were eluted by using $30 \mu \mathrm{L} 0.1 \%$ TFA, shaken for $10 \mathrm{~min}$, the digestion solution was transferred to a new $1.5 \mathrm{~mL}$ tube, and then the protein spots were eluted by using $70 \% \mathrm{v} / \mathrm{v}$ acetonitrile and $0.1 \% \mathrm{v} / \mathrm{v}$ trifluoroacetic acid twice, the digestion solution was then transferred to a new $1.5 \mathrm{~mL}$ tube once more, incorporating digestion solution, freezedried for $2 \mathrm{~h}$, condensing the volume to $10 \mu \mathrm{L}$ and stored in $-80^{\circ} \mathrm{C}$.

\section{Identification of Proteins by Mass Spectrometry}

The digestion solution was spotted on an MALDI target plate $(1.0 \mu \mathrm{L})$ twice and recrystallized CHCA matrix dissolved in $0.1 \%$ TFA/70\% ACN $(0.5 \mu \mathrm{L})$. Mass Standards Kit for Calibration of SCIEX MALDI-TOF Instrument (Foster City, CA, USA) was used for Mass assignment. Each sample spot was desalted with $0.01 \%$ TFA, and completely dried. Protein identification was conducted using an SCIEX MALDI TOF-TOF ${ }^{\mathrm{TM}} 5800$ Analyzer equipped with a neodymium. For the MS mode, peptide mass maps were acquired in positive reflection mode, and the 800$4,000 \mathrm{~m} / \mathrm{z}$ mass range was used with 4,000 laser shots per spectrum. A maximum of 20 precursors per spot with a minimum $\mathrm{S} / \mathrm{N}$ ratio of 20 were selected for MS/MS analysis in $2 \mathrm{kV}$ Positive modes. The contaminant $\mathrm{m} / \mathrm{z}$ peaks originating from trypsin auto-digestion, or matrix were excluded from MS/MS analysis.

A MS/MS results were analyzed by using ProteinPilot software (Foster City, CA, USA), and the results were searched using MASCOT software ${ }^{1}$. Matches to protein sequences from the Viridiplantae taxon (Green plants) in NCBInr database (updated 6 June 2014, 17893860 sequences) were considered acceptable if: (1) A protein score was obtained from MASCOT,

\footnotetext{
${ }^{1}$ http://www.matrixscience.com/
} 
which rates scores as significant if they are above the 95\% significance threshold ( $p<0.05)$; (2) At least two different predicted peptide masses matched the observed masses for an identification to be considered valid; (3) The coverage of protein sequences by the matching peptides should be higher than $5 \%$; (4) A parent ion mass tolerance of $\pm 0.2 \mathrm{Da}$ and an MS/MS tolerance of $\pm 0.1 \mathrm{Da}$; (5) Acetylation of the $\mathrm{N}$-terminus, cysteine as carboxylamidomethyl cysteine, pyroglu formation of $\mathrm{N}$-terminal Gln and methionine in an oxidized form were set as possible modifications. To understand the function of the proteins, the identified proteins were classified by using the MapMan ontology defined by Thimm et al. (2004).

\section{Quantitative Real-Time PCR}

Total RNA was isolated from the 10 days after flowering (DAF), 20 DAF, 30 DAF and mature seed using a TaKaRa MiniBEST Plant RNA Extration Kit (Tokyo City, Japan). cDNA was generated from the RNA with M-MLV reverse transcriptase (Tokyo City, Japan). Specific primers for quantitative realtime PCR (qRT-PCR) analysis were listed in Supplementary Table S1. Specificity of primers was checked by using NCBI database ${ }^{2}$, and the PCR products were sequenced (Supplementary Table S1). Reaction was carried out in $20 \mu \mathrm{L}$ reactions system containing $10 \mathrm{mM}$ Tris- $\mathrm{HCl}(\mathrm{pH} 8.5), 50 \mathrm{mM} \mathrm{KCl}, 2 \mathrm{mM}$ $\mathrm{MgCl}_{2}, 0.4 \mu \mathrm{L}$ DMSO, $200 \mathrm{mM}$ dNTPs, specific PCR primers $10 \mathrm{pmol} / \mu \mathrm{L}$, Taq DNA polymerase $1 \mathrm{U}$, SYBR GREEN I fluorescence dye $0.5 \mu \mathrm{L}$. qRT-PCR was performed in clear tubes using an Applied Biosystems ViiA ${ }^{\mathrm{TM}} 7$ Real-Time PCR System (Carlsbad City, CA, USA) as follows: $94^{\circ} \mathrm{C}$ for $5 \mathrm{~min}$, followed by 40 cycles at $94^{\circ} \mathrm{C}$ for $30 \mathrm{~s}, 58^{\circ} \mathrm{C}$ for $30 \mathrm{~s}, 72^{\circ} \mathrm{C}$ for $30 \mathrm{~s}$, and a final extension of $72^{\circ} \mathrm{C}$ for $5 \mathrm{~min}$. Actin was used as an internal control. All reactions were run in triplicate, Ct values were determined by the Applied Biosystems $\mathrm{ViiA}^{\mathrm{TM}} 7$ software with default settings. Differences between the $\mathrm{Ct}$ values of target gene and Actin were calculated as $\Delta \mathrm{Ct}=\mathrm{Ct}$ target gene $-\mathrm{Ct}$ Actin, and the relative expression levels of target genes were determined as $2^{-\Delta \mathrm{Ct}}$. For each sample, PCR was performed with three biological replicates. The average values of $2^{-\Delta \mathrm{Ct}}$ were used to determine difference in gene expression.

\section{RESULTS}

\section{The Variation of Grain Protein Content between Barley Cultivar Yangsimai 3 and Naso Nijo}

The GPC of Yangsimai 3 and Naso Nijo are 13.3 and 11.6\%, respectively (Figure 1), which indicates the GPC of Yangsimai 3 is $14.7 \%$ higher than Naso Nijo. Analysis shows the difference of GPC between the two cultivars is statistically significant $(p<0.01$; Figure 1).

\footnotetext{
${ }^{2}$ http://www.ncbi.nlm.nih.gov/tools/primer-blast/index.cgi?LINK_LOC=Blast Home
}

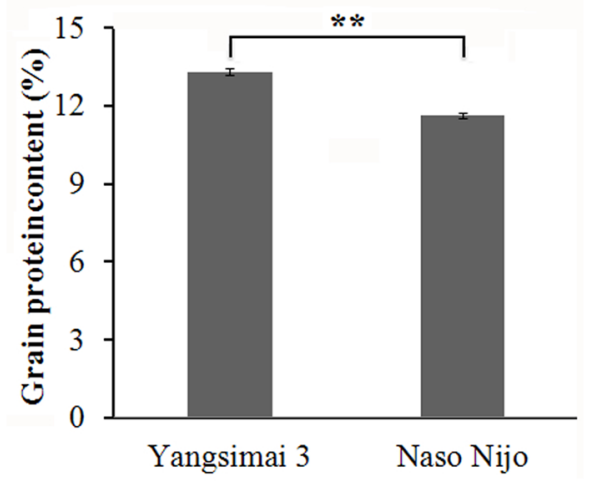

FIGURE 1 | Differences in grain protein content between two barley cultivars. ${ }^{* *} p<0.01$.

\section{Construction of a Differentially Expressed Protein Profiling of Grain Protein between Yangsimai 3 and Naso Nijo}

To construct a 2-DE map of barley grain proteins, grain proteins were separated by 2-DE with three biological replicates from Yangsimai 3 and Naso Nijo, respectively. At linear gradient of

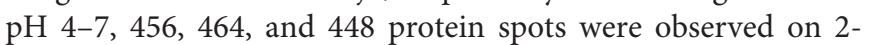
DE gels of Yangsimai 3, while 448, 460, and 452 protein spots were detected on 2-DE gels of Naso Nijo. At linear gradient of $\mathrm{pH} 6-11,59,55$, and 57 protein spots were detected on 2DE gels of Yangsimai 3, correspondingly, 58, 54, and 60 protein spots were detected on 2-DE gels of Naso Nijo (Figure 2; Supplementary Figure S2). Totally, 502 reproducibility protein spots were detected in both barley varieties, among which $41(41 / 502,8.17 \%)$ protein spots were found to be different pattern of expression between Yangsimai 3 and Naso Nijo by student's $t$-test at $p<5 \%$. When analyzing different pattern of expression between Yangsimai 3 and Naso Nijo, both quantitative and qualitative differences were observed. Student's $t$-test was used to calculate significant differences in relative abundance of protein spots in the Yangsimai 3 compared with Naso Nijo. The qualitative differences can be grouped into two categories, which were SEY (specific expressed in Yangsimai 3; 13 entries) and SEN (specific expressed in Naso Nijo; eight entries). The quantitative differences can be grouped into up-regulated or down-regulated in Yangsimai 3, with 13 and 7 protein spots in each category, respectively (Figure 3A).

\section{Identification of Differentially Expressed Protein Spots}

All differentially expressed protein spots between Yangsimai 3 and Naso Nijo were excised from representative 2-DE gels for identification, among which 34 protein spots were successfully identified by tandem MS, corresponding to 23 unique proteins (Supplementary Figures S2 and S3). These identified protein spots can be further grouped into eight categories according to their biological functions, and the category with the most proteins 

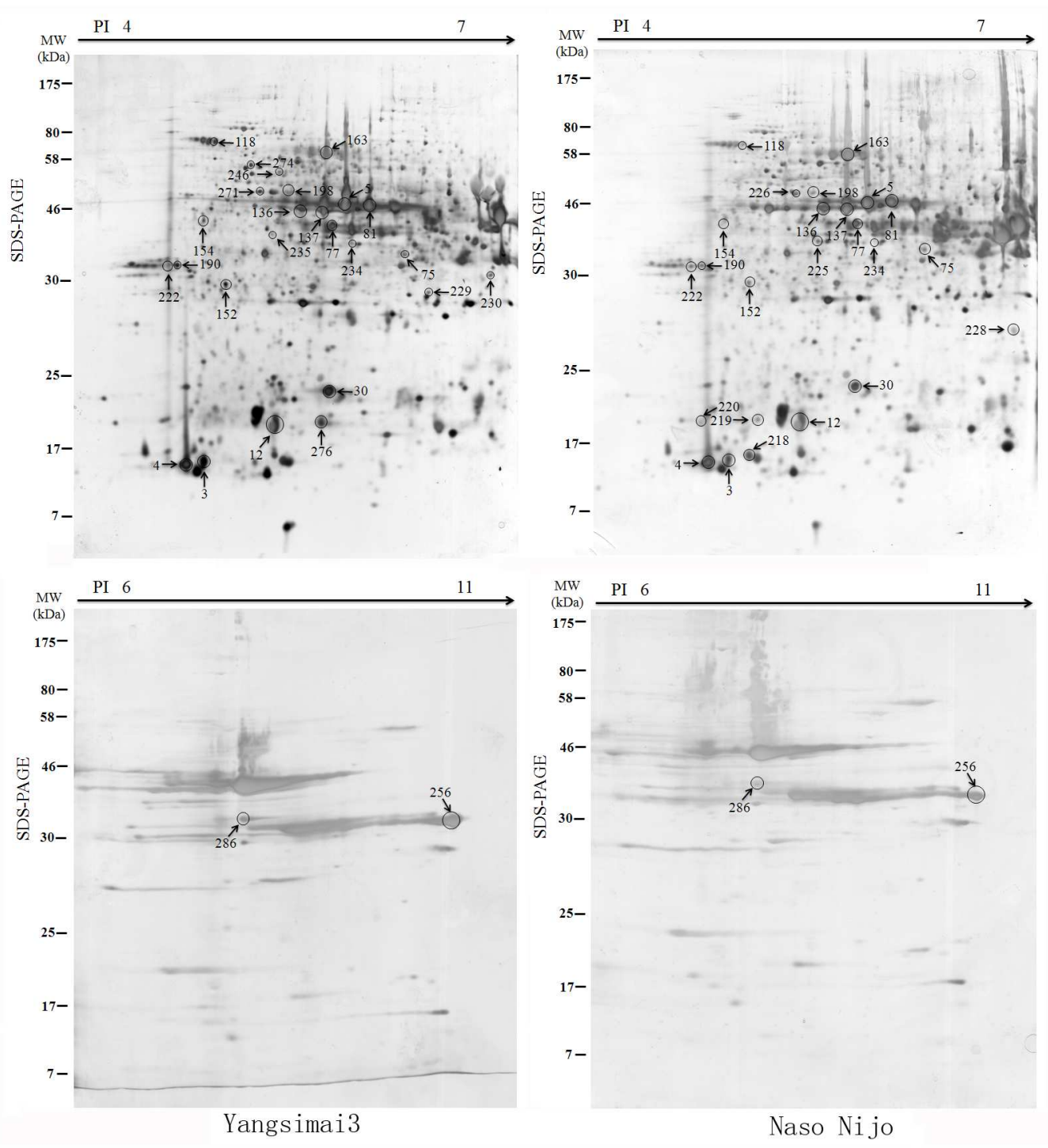

FIGURE 2 | The differentially expressed protein profiling between Yangsimai 3 and Naso Nijo.

identified was stress $(6 / 23,26.09 \%)$. The other categories referred to protein degradation and post-translational modification (three entries), development (two entries), cell (two entries), signaling (two entries), glycolysis (two entries), starch metabolism (two entries), and other function (four entries; Figure 3B).

Further analysis revealed that these 34 identified protein spots derived from 23 different genes or gene families, among which 14 gel spots corresponding to 14 protein isoform identifications collapsed to three proteins (Table 1, Supplementary Table S2). For example, spot 12, 30, 219, and 220 identified as globulin (gi|167004); spot 137, 154, 225, and 235 identified as serpin-Z7 (gi|75282567); spot 5, 75, 77, 81, 136, and 234 identified as protein serpin-Z4 (gi|1310677). The isoforms matched to the same sequence, though they differed significantly with respect to their $\mathrm{pIs}$ and $\mathrm{Mr}$ (Figure 4). The number of isoforms for each protein ranged from 4 to 6 . In the present study, four protein spots (spot
12, 30 219, and 220) were identified as globulin, which displayed an experimental Mr ranging from 20.380 to $22.147 \mathrm{kDa}$, less than the calculated $\mathrm{Mr}$ (637 aa, $72.551 \mathrm{kDa})$. MALDI-TOF MS/MS data which may be explained the $\mathrm{Mr}$ changes of the identified isoforms were summarized in Supplementary Table S2. All four protein spots were identified as C-terminal peptide sequences of globulin. In addition, some proteins have same protein name, but have different protein ID (Supplementary Table S2). For example, spot 190 (gi|22607) and 222 (gi|2492487) were identified as 143-3 protein, when aligned the two isoforms of 14-3-3 identified, it was shown that peptide 2 (LAEQAERYEEMVEFMEK) identified for gi|2492487 was common to both isoforms, whereas peptides 1 from each isoform (SAQDIALADLPTTHPIR and AAQEIALAELPPTHPIR) were unique and covered the same region of the proteins. Spot 198 (gi|326490934) and 274 (gi|326493636) were identified as enolase, both of them shared 
A

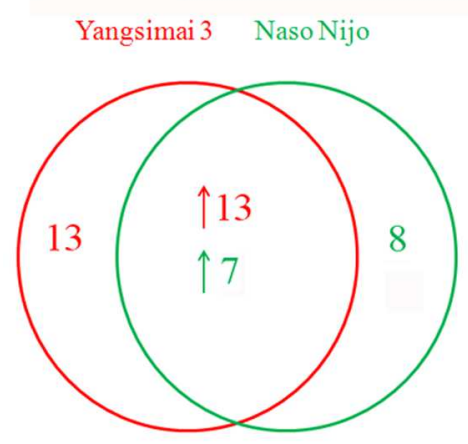

B

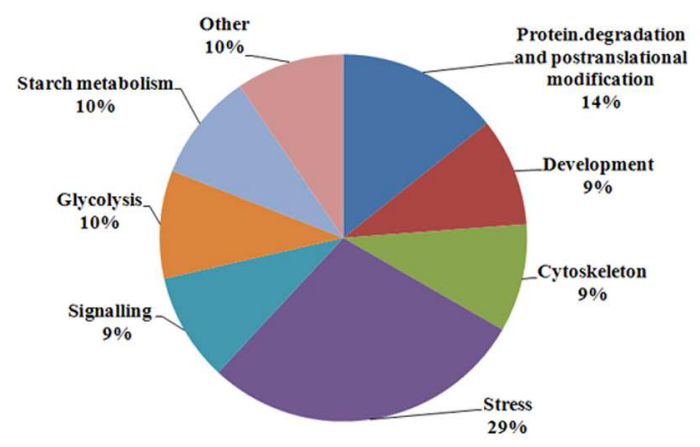

FIGURE 3 | The number of differentially expressed protein spots and protein function category. (A) The number of differentially expressed protein spots; (B) Function category of differentially expressed proteins.

high homology (98.44\%) and all of the peptides were common to both isoforms. Spot 9 (gi|326499406) and 118 (gi|326497219) were identified as heat shock cognate $70 \mathrm{kDa}$ protein, both of them shared $88.28 \%$ homology between two isoforms, all of the identified peptides were common to both isoforms except peptide 2 (STAGDTHLGGEDFDNR) from gi|326497219 was unique. Spot 256 (gi|224386) and 286 (gi|255348352) were identified as B hordein protein (Supplementary Table S2), both of them shared $67.29 \%$ homology between two isoforms, peptide 1 (TLPMMCSVNVPLYR and TLPTMCSVNVPLYR) and 2 (VFLQQQCSPVPVPQR and VFLQQQCSPVAMSQR) were unique and cover the same region of the protein isoforms, other peptides were common to both isoforms. Spot 3 (gi|585290) and 218 (gi|123970) were identified as alpha-amylase inhibitor, both of them contain a conserved AAI domain, all of the identified peptide for each isoforms were unique for each isoforms.

\section{Expression Analysis of Three Differentially Expressed Proteins on RNA Level}

To investigate whether differentially expressed proteins between Yangsimai 3 and Naso Nijo were also observed on the RNA level, genes encoding three proteins (spot 274, 218, and 271) were selected for qRT-PCR analysis (Figure 5). As shown in Figure 5, the expression levels of gene encoding ADP-glucose pyrophosphorylase (spot 271) increased with maturity, enolase (spot 274) increased and then decreased in mature seed, Alphaamylase inhibitor BDAI-1 (spot 218) increased from 10 to $30 \mathrm{DAF}$ but then dramatically decreased in mature seed. Comparison the expression pattern of three genes encoding differentially expression protein between protein level and RNA level in mature seed, genes encoding enolase, and small subunit of ADP-glucose pyrophosphorylase displayed higher expressed in Yangsimai3 than Naso Nijo on the RNA level, but specific expression in Yangsimai 3 in protein level (Figures 2 and 5). Remarkably, gene encoding Alpha-amylase inhibitor BDAI-1 showed the opposite expression patterns on the protein level compared with RNA level (Figures 2 and 5).

\section{Integration with Genomic Information}

To validate the potential implications of these functional annotations, the present results and those of a previous genetic analysis were integrated for GPC (Cai et al., 2013). Two proteins, including enolase and small subunit of ADPglucose pyrophosphorylase (gi|326493636 and gi|27464770) were identified in the present study, both of which were mapped to on chromosomes $5^{3}$ and positioned 44.17 and $47.01 \mathrm{cM}$ in barley, respectively. Remarkably, both proteins were closed to a QTL of controling barley GPC whose linkage marker was bPb-3412 at $45.6 \mathrm{cM}$ on Chr. 5 (Cai et al., 2013).

\section{DISCUSSION}

Barley cultivars used for malt should have a GPC not exceeding $11.5 \%$ (Pettersson and Eckersten, 2007). Actually, GPC is greatly affected by the growing environment. For instance, stresses caused by levels of nitrogen, drought, and/or heat may increase the GPC in barley (Savin and Nicolas, 1996; Qi et al., 2006). Therefore, it is important to breed cultivars with lower and less environmentally influenced GPC (Bertholdsson, 1999). In the current study, Yangsimai 3 was used as feed barley with GPC of $13.3 \%$, which displayed significant difference in GPC compared to Naso Nijo which was used as malting barley with GPC of $11.6 \%$, according to the data from 2013. Thus, these two cultivars provide good studying material to perform comparative proteome analysis and discover potential protein candidates involved in stable GPC expression and regulation.

Grain protein content is also influenced by genetic factors in barley. Genome-wide association study (GWAS) was performed by using 59 cultivated and 99 Tibetan wild barley genotypes for identifing molecular markers associated with GPC. Results

${ }^{3}$ http://webblast.ipk-gatersleben.de/barley/ 
TABLE 1 | Identified differentially expressed proteins between Yangsimai3 and Naso Nijo in mature barley grains.

\begin{tabular}{|c|c|c|c|c|c|c|}
\hline Spot no. & Protein name & Protein ID & $\begin{array}{l}\text { Experimental } \\
\mathrm{Mr}(\mathrm{Da}) / \mathrm{pl}\end{array}$ & $\begin{array}{l}\text { Calculated } \\
\mathrm{Mr}(\mathrm{Da}) / \mathrm{pl}\end{array}$ & Species & Expression pattern ${ }^{b}$ \\
\hline \multicolumn{7}{|l|}{ Cell } \\
\hline 226 & Actin & gi|326488133 & $42189 / 5.48$ & $41849 / 5.23$ & Hordeum vulgare & SEN \\
\hline 228 & Predicted protein & gi|297613620 & 27691/6.92 & $27303 / 4.93$ & Oryza sativa & SEN \\
\hline \multicolumn{7}{|c|}{ Development } \\
\hline 229 & Rab28 & gi|326531218 & $31690 / 6.41$ & $30439 / 5.23$ & Hordeum vulgare & SEY \\
\hline 12 & Globulin & gi|167004 & $20412 / 5.45$ & $72551 / 6.80$ & Hordeum vulgare & Up-regulated \\
\hline 30 & Globulin & gi|167004 & $22147 / 5.72$ & $72551 / 6.81$ & Hordeum vulgare & Up-regulated \\
\hline 219 & Globulin & gi|167004 & $20386 / 5.23$ & $72551 / 6.80$ & Hordeum vulgare & SEN \\
\hline 220 & Globulin & gi|167004 & 20380/4.72 & $72551 / 6.80$ & Hordeum vulgare & SEN \\
\hline \multicolumn{7}{|c|}{ Glycolysis } \\
\hline 198 & Enolase & gi|326490934 & $42163 / 5.56$ & $48601 / 5.39$ & Hordeum vulgare & Up-regulated \\
\hline 274 & Enolase & gi|326493636 & $52435 / 5.31$ & $48427 / 5.39$ & Hordeum vulgare & SEY \\
\hline \multicolumn{7}{|c|}{ Protein degradation and post-translational modification } \\
\hline 5 & Serpin-Z4 & gi|1310677 & $40675 / 5.81$ & $43307 / 5.61$ & Hordeum vulgare & Down-regulated \\
\hline 75 & Serpin-Z4 & gil1310677 & $37625 / 6.24$ & $43307 / 5.61$ & Hordeum vulgare & Down-regulated \\
\hline 77 & Serpin-Z4 & gi|1310677 & $38134 / 5.73$ & $43307 / 5.61$ & Hordeum vulgare & Up-regulated \\
\hline 81 & Serpin-Z4 & gi|1310677 & $40580 / 6.01$ & $43307 / 5.61$ & Hordeum vulgare & Up-regulated \\
\hline 136 & Serpin-Z4 & gi|1310677 & $40172 / 5.60$ & $43307 / 5.61$ & Hordeum vulgare & Down-regulated \\
\hline 234 & Serpin-Z4 & gi|1310677 & $36214 / 5.92$ & $43307 / 5.61$ & Hordeum vulgare & Up-regulated \\
\hline 137 & Serpin-Z7 & gi|75282567 & $40021 / 5.7$ & $42851 / 5.45$ & Hordeum vulgare & Down-regulated \\
\hline 154 & Serpin-Z7 & gi|75282567 & $39041 / 4.92$ & $42851 / 5.45$ & Hordeum vulgare & Up-regulated \\
\hline 225 & Serpin-Z7 & gi|75282567 & $36300 / 5.60$ & $42851 / 5.45$ & Hordeum vulgare & SEN \\
\hline 235 & Serpin-Z7 & gi|75282567 & $37205 / 5.42$ & $42851 / 5.46$ & Hordeum vulgare & SEY \\
\hline 230 & $\begin{array}{l}\text { Guanine nucleotide-binding protein } \\
\text { subunit beta-like protein }\end{array}$ & gi|326491885 & $33456 / 6.90$ & $36655 / 5.97$ & Hordeum vulgare & SEY \\
\hline \multicolumn{7}{|l|}{ Signaling } \\
\hline 190 & 14-3-3 protein homolog & gil22607 & $34126 / 4.77$ & $29361 / 4.83$ & Hordeum vulgare & Up-regulated \\
\hline 222 & 14-3-3-like protein B & gi|2492487 & $34088 / 4.65$ & $29787 / 4.67$ & Hordeum vulgare & Down-regulated \\
\hline \multicolumn{7}{|c|}{ Starch metabolism } \\
\hline 163 & Beta-amylase 1 & gi|38349539 & $62321 / 5.70$ & $57883 / 5.65$ & Hordeum vulgare & Down-regulated \\
\hline 271 & $\begin{array}{l}\text { Small subunit of ADP-glucose } \\
\text { pyrophosphorylase }\end{array}$ & gil27464770 & $42163 / 5.35$ & $43861 / 4.91$ & Hordeum vulgare & SEY \\
\hline \multicolumn{7}{|l|}{ Stress } \\
\hline 3 & Alpha-amylase/trypsin inhibitor CMb & gi|585290 & $17054 / 4.91$ & $17199 / 5.77$ & Hordeum vulgare & Up-regulated \\
\hline 4 & CMd preprotein & gi|758343 & $16256 / 4.75$ & $17894 / 5.24$ & Hordeum vulgare & Up-regulated \\
\hline 218 & Alpha-amylase inhibitor BDAl-1 & gi|123970 & $18374 / 5.20$ & $17045 / 5.36$ & Hordeum vulgare & SEN \\
\hline 118 & Heat shock cognate 70 kDa protein & gi|326497219 & $71675 / 5.13$ & $72202 / 5.14$ & Hordeum vulgare & Up-regulated \\
\hline 9 & Heat shock cognate 70 kDa protein & gi|326499406 & $70654 / 4.95$ & $71629 / 5.09$ & Hordeum vulgare & Down-regulated \\
\hline 276 & $17 \mathrm{kDa}$ class I small heat shock protein & gi|1536911 & $20653 / 5.68$ & $16832 / 5.83$ & Hordeum vulgare & SEY \\
\hline \multicolumn{7}{|l|}{ Others } \\
\hline 152 & Lactoylglutathione lyase & gi|326493416 & $31.890 / 5.20$ & $32811 / 5.34$ & Triticum aestivum & Up-regulated \\
\hline 246 & ATP synthase beta subunit & gi|326492854 & $48524 / 5.51$ & $59434 / 5.85$ & Hordeum vulgare & SEY \\
\hline 256 & B hordein & gi|224386 & $31556 / 11.4$ & $30850 / 8.26$ & Hordeum vulgare & Up-regulated \\
\hline 286 & B hordein & gi|255348352 & $30782 / 7.55$ & $30621 / 7.95$ & Hordeum vulgare & Up-regulated \\
\hline
\end{tabular}

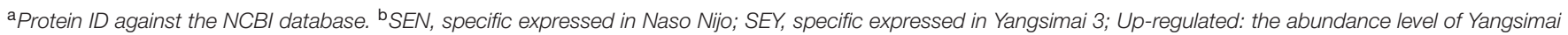
3 is higher than Naso Nijo; Down-regulated: the abundance level of Yangsimai 3 is lower than Naso Nijo.

showed a total of 10 DArT markers $(p<0.01)$ were associated with GPC in barley (Cai et al., 2013). Further analysis indicated that $H v N A M$ genes could play a role in controlling barley GPC (Cai et al., 2013). Variation in protein expression profiles of barley cultivars reflected genetic variations, which was illustrated by the identification of different alleles of $\beta$-amylase in two protein spots
(Finnie et al., 2002). For example, Barke and Morex are two malting cultivars different in seed maturation days. Comparative proteomics analysis revealed that differentially expressed proteins reflected the faster maturation of Morex seeds (Finnie et al., 2006). In the current study, a differentially expressed proteins profiling of barley mature seed was constructed. Among the 


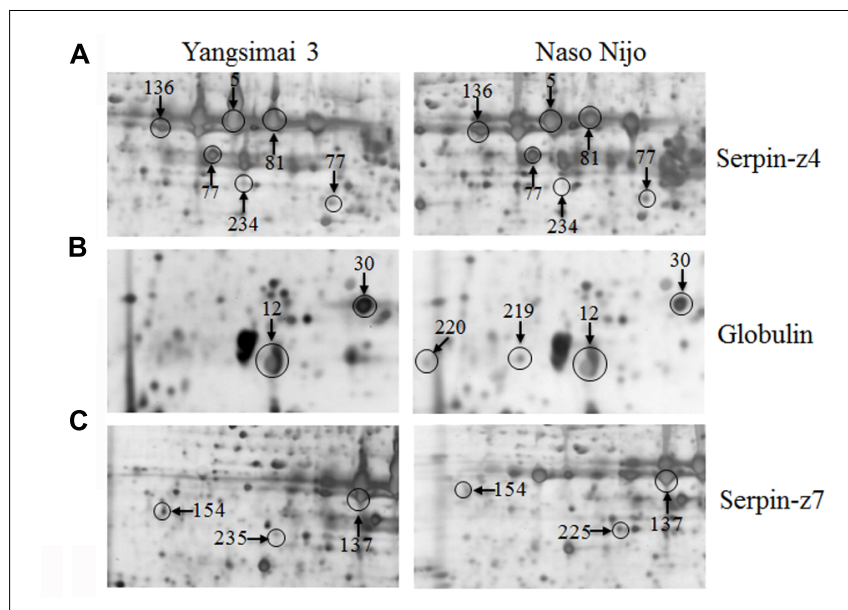

FIGURE 4 | Protein isoforms were observed on 2-DE gels. Serpin-Z4 (A), Globulin (B), and Serpin-Z7 (C) isoforms which were observed on Yangsimai 3 and Naso Nijo 2-DE gels.

502 protein spots that were reproducibly detected, a total of 34 differentially expressed protein spots were identified by tandem MS, which corresponded to 23 different proteins.

ADP-glucose pyrophosphorylase (AGPase) catalyzes the conversion of Glc-1-P and ATP to PPi and ADP-glucose, and is a key regulatory enzyme of starch biosynthesis (Preiss et al., 1991; Tetlow et al., 2004; Geigenberger, 2011). In barley, AGPase gene generates two transcripts, one of which encodes the cytosolic small subunits of ADP-glucose pyrophosphorylase in the endosperm and another encodes the plastidial SSU in leaves (Beckles et al., 2001). The Risø16 mutant of barley lacks cytosolic AGPase activity in the endosperm, which leads to decreased grain weight. Also, Risø16 mutant contained 90\% total $\mathrm{N}$ and proteins of wild type at the transcriptional level, down-regulated enolase and beta-amylase 1 (Faix et al., 2012). In the present study, protein spot 274 and 271 were identified as enolase (gi|326493636) and small subunit of ADP-glucose pyrophosphorylase (gi|27464770), respectively, both of which were higher expressed in Yangsimai 3 than in Naso Nijo on the protein and RNA levels. Genomic information verified that the two proteins are close to a QTL for GPC (bPb-3412) on Chr. 5 (Cai et al., 2013). Integrating the above genomic results, the comparative expressions from our current study indicated that the specific expression of enolase (spot 274) and small subunit of ADP-glucose pyrophosphorylase (spot 271) in barley Yangsimai 3 could contribute to the GPC in barley seed.

Prolamins is the major storage proteins in barley seed protein, which is specifically synthesized in the starchy endosperm and divided into $\mathrm{B}, \mathrm{C}, \mathrm{D}$ and $\gamma$ hordeins according to their mobility in SDS-electrophoretic gels (Kreis and Shewry, 1992; Piston et al., 2005). Among the four types of hordeins, B fraction accounts for $70-80 \%$ of the total prolamins content in most barley cultivars. Previous studies reported that B hordein was significantly correlated with GPC, B hordein content increased as the sowing date was postponed and was significantly affected by nitrogen levels (Qi et al., 2005, 2006). In the present study, two protein spots (spot 256 and 286) were identified as B hordein, and also displayed up-regulated in Yangsimai 3, which would contribute to the difference of GPC in mature barley seeds.

Serpins are the most abundant proteins in beer 2DE gels, and characterized by their function in malting barley (Jin et al., 2013). It was widely believed that serpins are beer foam-positive proteins and improve malt filterability (Maceda et al., 1991; Jin et al., 2013). In barley, serpin was approximately $43-\mathrm{kDa}$ polypeptide, which irreversibly inhibits the endogenous and exogenous target proteinases (Roberts and Hejgaard, 2008). Comparative proteomics based on fluorescent difference gel electrophoresis (DIGE) was employed to quantitatively analyze proteins in cultivars Dan'er and Metcalfe in China, and the results showed that serpin $\mathrm{Z} 4$ and $\mathrm{Z} 7$ were the most remarkable differentially expressed proteins, which played an important role in malt filterability (Jin et al., 2013). Interestingly, mutiple protein isoforms of serpin Z4 and Z7 were observed in barley seed proteome (Finnie et al., 2002; Jin et al., 2013). In the present study, 10 protein spots were identified as serpin (serpin Z4 and Z7) and displayed multiple expression patterns (Table 1; Supplementary Table S2). In addition, globulin, which undergoes post-translational processing, is an important seed storage protein in cereal crops and functions in glycosylation and partial endoproteolytic cleavage (Heck et al., 1993; Herman and Larkins, 1999). In wheat, globulin-3 was cleaved post-translationally in embryos. Five major polypeptide spots of globulin-3 were identified by MS and N-terminal sequencing, and each spot displayed different $\mathrm{Mr}$ and $\mathrm{pI}$, these post-translational processing events that lead to the maturation of the globulin family of proteins observed seed protein fraction that could be associated with type 1 diabetes or celiac disease following endoproteolytic processing (Koziol et al., 2012). In barley, globulin contains 637 amino acids with one signal peptide detected by the SignalP v4.0 program, the peptide starts at position 1 and ends at position 27. Four protein spots (spot 12, 30, 219, and 220) were identified as barely globulin in the current study, the MALDITOF MS/MS result revealed that the four protein spots only contains several fragments of the globulin, it is suggesting that globulin undergo cleavage of signal peptide from precursor, or non-specific degradation pathway.

The proteinaceous barley alpha-amylase/subtilisin inhibitor (BASI) is synthesized during grain filling and is an abundant protein of the endosperm and the aleurone layers of the mature seed (Mundy et al., 1983; Lecommandeur et al., 1987; Leah and Mundy, 1989). Recently, alpha-amylase inhibitor (BDAI1) and $\mathrm{CMb}$ component of tetrameric alpha amylase inhibitor $(\mathrm{CMb})$ were identified by using MS analysis. All of them were differentially expressed among four haze samples; further analysis indicated that BDAI-1, CMb were not predominant haze-active proteins, but growth factors of beer colloidal haze (Iimure et al., 2009). Two alpha-amylase inhibitors were identified in the current study, which were Alpha-amylase inhibitor BDAI1 (spot 218) and CMb (spot 3) displayed specific expressed and down-regulated pattern in Naso Nijo, respectively. Dramatically, Alpha-amylase inhibitor BDAI-1 displayed higher expression in Yangsimai 3 than in Naso Nijo on the RNA level. These 

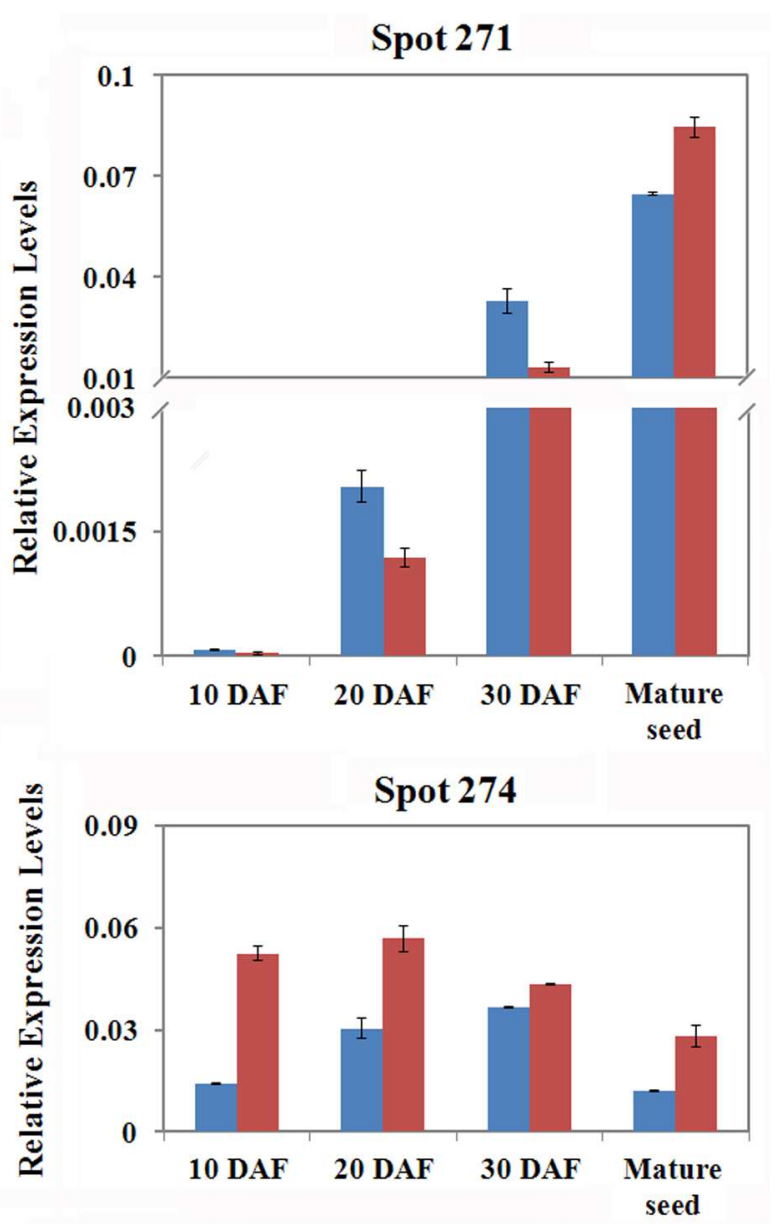

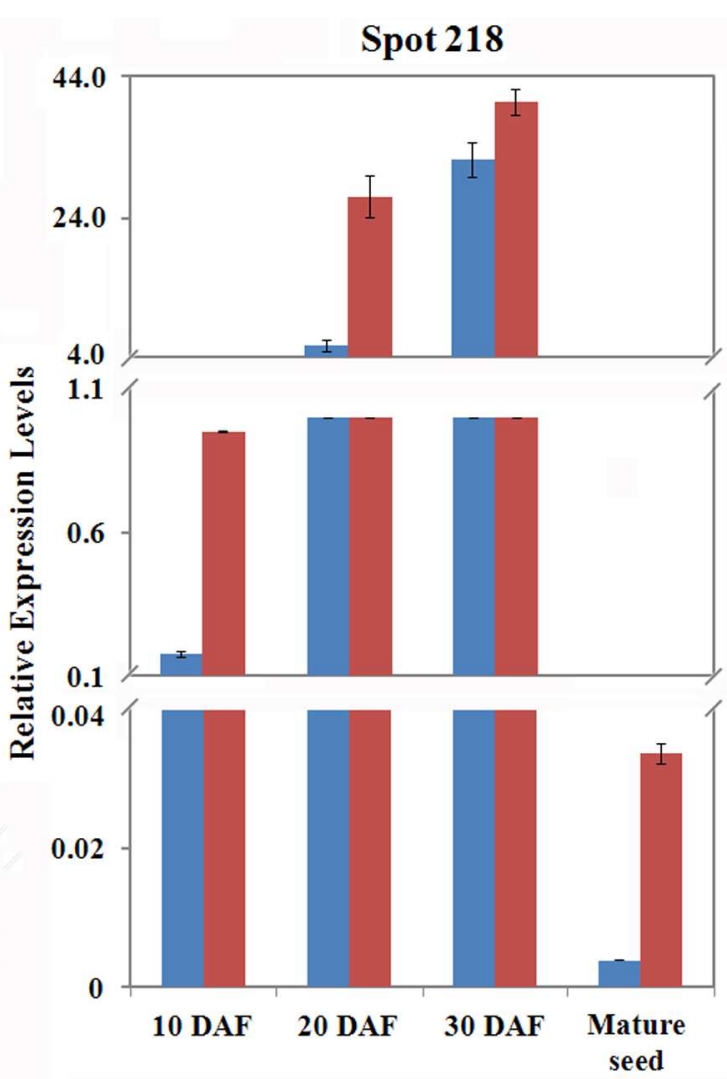

$\square$ Naso Nijio $\quad$ Yangsimai 3

FIGURE 5 | Quantitative real-time PCR of mRNA expression patterns for selected protein spots in 10 DAF (days after flowering), 20 DAF, 30 DAF and mature seed.

data suggested that different members in the protease inhibitor family may have different functions in barley cultivars, and also the mRNA of BDAI-1 maybe undergo post-transcriptional processing in the seed development. However, detailed studies on alpha-amylase inhibitor may facilitate a better understanding of the mechanisms involved in malting barley.

\section{CONCLUSION}

In the present study, the GPC was significant difference in Yangsimai 3 and Naso Nijo. A differentially expressed profiling of grain proteins was established by using a combination of 2DE and tandem MS. In total, 41 protein spots were detected differentially expressed between Yangsimai 3 and Naso Nijo, among which 34 protein spots corresponding to 23 different proteins were identified. In particular, differentially expressed proteins from the seed were mainly related to stress, protein degradation and post-translational modification, development, cell, signaling, glycolysis and starch metabolism. Seeds proteome explicitly displays that differentially expressed proteins are involved in GPC and malting quality. However, a malting barley cultivar is quite different from a feed barley cultivar and there is an interest to develop a greater knowledge of the determinants of malting and feed quality at the protein level, in order to improve the evaluation of new barley varieties. The quality of the barley is determined in part by the proteins content produced during grain filling, meanwhile the accumulation of storage proteins plays an important role in seed development by regulating the appearance of proteins in different development stages. Therefore, an understanding of the mechanism of how storage proteins accumulation initiates during seed development is required to be further investigated.

\section{AUTHOR CONTRIBUTIONS}

BG and HL carried out the seed proteins preparation, 2-DE analysis, mass spectrometry analysis and interpretation of the 2DE data, and wrote portions of the manuscript. SL, CL, and XZ carried out image analysis and 2-DE data. BG and RX conceived of the project and wrote a draft of the manuscript and provided 
conceptual framework. All authors read and approved of the final manuscript.

\section{FUNDING}

This research was funded by the National Natural Science Foundation of China 31401370, National Barley and Highland Barley Industrial Technology Specially Constructive Foundation of China (CARS-05), A Project Funded by the Priority Academic Program Development of Jiangsu Higher Education Institutions, Jiangsu Agriculture Science and Technology Innovation Fund [CX(14)5093], Jiangsu Provincial Key Laboratory Open Project 205031310.

\section{REFERENCES}

Beckles, D. M., Smith, A. M., and ap Rees, T. (2001). A Cytosolic ADPglucose pyrophosphorylase is a feature of graminaceous endosperms, but not of other starch-storing organs. Plant Physiol. 125, 818-827. doi: 10.1104/pp. 125.2.818

Bertholdsson, N. O. (1999). Characterization of malting barley cultivars with more or less stable grain protein content under varying environmental conditions. Eur. J. Agron. 10, 1-8. doi: 10.1016/S1161-0301(98)00043-4

Bradford, M. M. (1976). A rapid and sensitive method for the quantitation of microgram quantities of protein utilizing the principle of protein-dye binding. Anal. Biochem. 72, 248-254. doi: 10.1006/abio.1976.9999

Cai, S. G., Yu, G., Chen, X. H., Huang, Y. C., Jiang, X. G., Zhang, G. P., et al. (2013). Grain protein content variation and its association analysis in barley. BMC Plant Biol. 13:35. doi: 10.1186/1471-2229-13-35

Clancy, J. A., Han, F., and Ullrich, S. E. (2003). The North American barley genome project: comparative mapping of $\beta$-amylase activity QTLs among three barley crosses. Crop Sci. 43, 1043-1052. doi: 10.2135/cropsci 2003.1043

Dong, M. H., Gu, J. R., Zhang, L., Chen, P. F., Liu, T. F., Deng, J. H., et al. (2014). Comparative proteomics analysis of superior and inferior spikelets in hybrid rice during grain filling and response of inferior spikelets to drought stress using isobaric tags for relative and absolute quantification. J. Proteom. 109, 382-399. doi: 10.1016/j.jprot.2014.07.001

Eagles, H. A., Bedggood, A. G. J., Panozzo, F., and Martin, P. J. (1995). Cultivar and environmental effects on malting quality in barley. Aust. J. Agric. Res. 46, 831-844. doi: 10.1071/AR9950831

Faix, B., Radchuk, V., Nerlich, A., Hümmer, C., Radchuk, R., Emery, R. J. N., et al. (2012). Barley grains, deficient in cytosolic small subunit of ADP-glucose pyrophosphorylase, reveal coordinate adjustment of $\mathrm{C}$ : $\mathrm{N}$ metabolism mediated by an overlapping metabolic-hormonal control. Plant J. 69, 1077-1093. doi: 10.1111/j.1365-313X.2011.04857.x

Finnie, C., Bak-Jensen, K. S., Laugesen, S., Roepstorff, P., and Svensson, B. (2006). Differential appearance of isoforms and cultivar variation in protein temporal profiles revealed in the maturing barley grain proteome. Plant Sci. 170, 808-821. doi: $10.1016 /$ j.plantsci.2005.11.012

Finnie, C., Melchior, S., Roepstorff, P., and Svensson, B. (2002). Proteome analysis of grain filling and seed maturation in barley. Plant Physiol. 129, 1308-1319. doi: 10.1104/pp.003681

Ge, P., Ma, C., Wang, S., Gao, L., Li, X., Guo, G., et al. (2012). Comparative proteomic analysis of grain development in two spring wheat varieties under drought stress. Anal. Bioanal. Chem. 402, 1297-1313. doi: 10.1007/s00216-0115532-z

Geigenberger, P. (2011). Regulation of starch biosynthesis in response to a fluctuating environment. Plant Physiol. 155, 1566-1577. doi: 10.1104/pp.110.170399

Guillon, F., Larré, C., Petipas, F., Berger, A., Moussawi, J., Rogniaux, H., et al. (2012). A comprehensive overview of grain development in Brachypodium distachyon variety Bd21. J. Exp. Bot. 63, 739-755. doi: 10.1093/jxb/err298

\section{ACKNOWLEDGMENT}

The authors wish to thank Dr. Yuyang Wang for his assistance in mass spectrometry analysis.

\section{SUPPLEMENTARY MATERIAL}

The Supplementary Material for this article can be found online at: http://journal.frontiersin.org/article/10.3389/fpls.2016.00542

FIGURE S1 | The standard curve for protein concentration determination. FIGURE S2 | All the replicates 2-DE gels in the present study. FIGURE S3 | Expression patterns for differentially expressed protein spots. ${ }^{*} p<0.05,{ }^{* *} p<0.01$.

Guo, G. F., Lv, D. W., Yan, X., Subburaj, M., Ge, P., Li, X. H., et al. (2012). Proteome characterization of developing grains in bread wheat cultivars (Triticum aestivum L.). BMC Plant Biol. 12:147. doi: 10.1186/1471-2229-12-147 Heck, G. R., Chamberlain, A. K., and Ho, T. H. D. (1993). Barley embryo globulin1 gene, beg1: characterization of cDNA, chromosome mapping and regulation of expression. Mol. Gen. Genet. 239, 209-218. doi: 10.1007/BF00281620

Herman, E., and Larkins, B. (1999). Protein storage bodies and vacuoles. Plant Cell 11, 601-613. doi: 10.1105/tpc.11.4.601

Howard, K. A., Gayler, K. R., Eagles, H. A., and Halloran, G. M. (1996). The relationship between D hordein and malting quality in barley. J. Cereal Sci. 24, 47-53. doi: 10.1006/jcrs.1996.0036

Hurkman, W. J., and Tanaka, C. K. (2007). Extraction of wheat endosperm proteins for proteome analysis. J. Chromatogr. B 849, 344-350. doi: 10.1016/j.jchromb.2006.11.047

Iimure, T., Nankaku, N., Watanabe-Sugimoto, M., Hirota, N., Tiansu, Z., and Kihara, M. (2009). Identification of novel haze-active beer proteins by proteome analysis. J. Cereal Sci. 49, 141-147. doi: 10.1016/j.jcs.2008.08.004

Jiang, C. M., Chengm, Z. Q., Cheng, Z., Yu, T. Q., Zhong, Q. F., Shen, Q. X., et al. (2014). Proteomic analysis of seed storage proteins in wild rice species of the Oryza genus. Proteome Sci. 12:51. doi: 10.1186/s12953-014-0051-4

Jin, Z., Li, X. M., Gao, F., Sun, J. Y., Mu, Y. W., and Jian, L. (2013). Proteomic analysis of differences in barley (Hordeum vulgare) malts with distinct filterability by DIGE. J. Proteom. 93, 93-106. doi: 10.1016/j.jprot.2013.05.038

Kim, Y. J., Lee, H. M., Wang, Y. M., Wu, J. N., Kim, S., Kang, K. Y., et al. (2013). Depletion of abundant plant rubisco protein using the protamine sulfate precipitation method. Proteomics 13, 2176-2179. doi: 10.1002/pmic. 201200555

Kjeldahl, J. Z. (1883). A new method for the determination of nitrogen in organic matter. Z. Anal. Chem. 22, 366-382. doi: 10.1007/BF01338151

Koziol, A. G., Loit, E., McNulty, M., MacFarlane, A. J., Scott, F. W., and Altosaar, I. (2012). Seed storage proteins of the globulin family are cleaved post-translationally in wheat embryos. BMC Res. 5:385. doi: 10.1186/17560500-5-385

Kreis, M., and Shewry, P. R. (1992). "The control of protein synthesis in developing barley seeds," in Barley: Genetics, Molecular Biology and Bio/Technology, ed. P. R. Shewry (Wallingford: CAB International).

Leah, R., and Mundy, J. (1989). The bifunctionala-amylase/subtilisin inhibitor of barley: nucleotide sequence and patterns of seed-specific expression. Plant Mol. Biol. 12, 673-682. doi: 10.1007/BF00044158

Lecommandeur, D., Lauriére, C., and Daussant, J. (1987). $\alpha$-Amylase inhibitor in barley seeds: localization and quantification. Plant Physiol. Biochem. 25, 711-715.

Maceda, K., Yokoi, S., Kamada, K., and Kaminura, M. (1991). Foam stability and physicochemical properties of beer. J. Am. Soc. Brew. Chem. 49, 14-18.

Mundy, J., Svendsen, I., and Hejgaard, J. (1983). Barley $\alpha$-amylase/subtilisin inhibitor: I. Isolation and characterization. Carlsberg Res. Commun. 48, 81-91. doi: 10.1007/BF02906171

Pettersson, C. G., and Eckersten, H. (2007). Prediction of grain protein in spring malting barley grown in northern Europe. Eur. J. Agron. 27, 205-214. doi: 10.1016/j.eja.2007.04.002 
Piston, F., Martin, A., Dorado, G., and Barro, F. (2005). Cloning and molecular characterization of B-hordeins from Hordeum chilense (Roem. et Schult). Theor. Appl. Genet. 111, 551-560. doi: 10.1007/s00122-005-2046-0

Preiss, J., Ball, K., Smith-White, B., Iglesias, A., Kakefuda, G., and Li, L. (1991). Starch biosynthesis and its regulation. Biochem. Soc. Trans. 19, 539-547. doi: 10.1042/bst0190539

Qi, J. C., Chen, J. X., Wang, J. M., Wu, F. B., Cao, L. P., and Zhang, G. P. (2005). Protein and hordein fraction content in barley seeds as affected by sowing date and their relations to malting quality. J. Zhejiang Univ. Sci. 6B, 1069-1075. doi: 10.1631/jzus.2005.B1069

Qi, J. C., Zhang, G. P., and Zhou, M. X. (2006). Protein and hordein content in barley seeds as affected by nitrogen level and their relationship to beta-amylase activity. J. Cereal Sci. 43, 102-107. doi: 10.1016/j.jcs.2005.08.005

Roberts, T. H., and Hejgaard, J. (2008). Serpins in plants and green algae. Funct. Integr. Genom. 8, 1-27. doi: 10.1007/s10142-007-0059-2

Savin, R., and Nicolas, M. E. (1996). Effects of short periods of drought and high temperature on grain growth and starch accumulation of two malting barley cultivars. Funct. Plant Biol. 23, 201-210. doi: 10.1071/PP9960201

See, D. K., Kephart, V., and Blake, K. (2002). Mapping genes controlling variation in barley grain protein concentration. Crop Sci. 2002, 680-685. doi: $10.2135 /$ cropsci2002.0680

Sun, H. Y., Cao, F. B., Wang, N. B., Zhang, M., Ahmed, I. M., Zhang, G. P., et al. (2013). Differences in grain ultrastructure, phytochemical and proteomic profiles between the two contrasting grain $\mathrm{Cd}$-accumulation barley genotypes. PLoS ONE 8:e79158. doi: 10.1371/journal.pone.0079158
Tetlow, I. J., Morell, M. K., and Emes, M. J. (2004). Recent developments in understanding the regulation of starch metabolism in higher plants. J. Exp. Bot. 55, 2131-2145. doi: 10.1093/jxb/erh248

Thimm, O., Bläsing, O., Gibon, Y., Nagel, A., Meyer, S., Krüger, P., et al. (2004). MAPMAN: a user-driven tool to display genomics data sets onto diagrams of metabolic pathways and other biological processes. Plant J. 37, 914-939. doi: 10.1111/j.1365-313X.2004. 02016.x

Wang, J. M., Zhang, G. P., Chen, J. X., Ding, S. R., and Zhou, T. Y. (2003). Variation of grain and malt qualities in barley as affected by cultivars and environments. Agric. Sci. China 2, 699-705.

Weston, D. T., Horsley, R., Schwarz, P. B., and Goos, R. J. (1993). Nitrogen and planting date effects on low-protein spring barley. Agron. J. 85, 1170-1174. doi: 10.2134/agronj1993.00021962008500060015x

Conflict of Interest Statement: The authors declare that the research was conducted in the absence of any commercial or financial relationships that could be construed as a potential conflict of interest.

Copyright (c) 2016 Guo, Luan, Lin, Lv, Zhang and Xu. This is an open-access article distributed under the terms of the Creative Commons Attribution License (CC BY). The use, distribution or reproduction in other forums is permitted, provided the original author(s) or licensor are credited and that the original publication in this journal is cited, in accordance with accepted academic practice. No use, distribution or reproduction is permitted which does not comply with these terms. 